\title{
Dinamika perubahan garis pantai Kabupaten Kendal tahun 2000-2020
}

\author{
Bernadetta Indri D $\mathbf{A}^{\mathbf{1}}$, Agung Laksono ${ }^{1}$, Dzakwan Taufiq $\mathbf{N}^{\mathbf{1}}$, Intan Fatin $\mathbf{N}^{1}$, Noverita Nur $\mathbf{H}^{1}$, Oki Silvie $\mathbf{W}^{1}$, \\ Ramadhani Nurazizah $\mathbf{J}^{1}$, Muh Aris Marfai ${ }^{*}$ \\ ${ }^{I}$ Departemen Geografi Lingkungan, Fakultas Geografi, Universitas Gadjah Mada, Yogyakarta, Indonesia
}

\section{Koresponden Email: arismarfai@gadjahmada.edu}

Direvisi: 2020-12-16 . Diterima: 2021-02-18

(C)2021 Fakultas Geografi UGM dan Ikatan Geograf Indonesia (IGI)

\begin{abstract}
Abstrak Pemantauan garis pantai akibat adanya proses akresi dan abrasi merupakan salah satu upaya untuk menjaga batas wilayah wilayah di Kabupaten Kendal. Lima multitemporal citra Landsat 7 ETM+ dalam periode tahun 20 tahun (2000-2020) digunakan untuk menganalisis perubahan garis pantai di Kabupaten Kendal.Tujuan dari penelitian ini adalah untuk menganalisis perubahan garis pantai dan menganalisis dampak serta upaya mitigasi dalam menangani perubahan garis pantai di Kabupaten Kendal. Digital Shoreline Analysis System (DSAS) digunakan untuk menganalisis perubahan garis pantai dengan metode Net Shoreline Movement (NSM), End Point Rate (EPR), dan Linear Regression Rate-of-Change (LRR). Hasil penelitian menunjukkan bahwa nilai tertinggi dari Linear Regression Rate-of-Change (LRR) selama periode 20 tahun adalah sebesar 50,9 m/tahun sedangkan nilai terendah sebesar -35,81 meter/tahun. Nilai rata-rata EPR dan NSM selama periode 20 tahun adalah sebesar $-0,07 \mathrm{~m} / \operatorname{tahun}$ dan $-1,14$ meter. Berdasarkan studi ini, dampak dari perubahan garis pantai yang disebabkan abrasi dan akresi adalah adanya peningkatan dan penurunan luas wilayah. Bentuk mitigasi perubahan garis pantai di Kabupaten Kendal yakni dengan pembangunan breakwater dan penanaman hutan mangrove.
\end{abstract}

Kata kunci: abrasi, akresi, NSM, EPR, LRR

\begin{abstract}
Monitoring shoreline change due to accretion and abrasion processes is one of the efforts to protect the maritime boundary of Kendal Regency. Five multi-temporal Landsat 7 ETM + images spanning 20 years (2000-2020) is used in the tudy for the analysis of shoreline change in Kendal Regency. This study aims to investigate the shoreline change, analyze the impact, and propose mitigation of shoreline change in Kendal Regency as well. Digital Shoreline Analysis System (DSAS) is utilized for the analysis of the shoreline change through Net Shoreline Movement (NSM), End Point Rate (EPR), and Linear Regression Rate-of-Change (LRR). The result shows that the highest value of the Linear Regression Rate (LRR) for 20 years is $50.09 \mathrm{~m} /$ year and the lowest value of LRR is $-35.81 \mathrm{~m} /$ year. The average EPR and NSM are $-0.07 \mathrm{~m} /$ years and $-1.14 \mathrm{~m}$. From this study, it can be observed that the impact of shoreline change induced by accretion and abrasion are the addition and subtraction of the predetermined area. The impacts can be mitigated by building breakwaters and planting mangroves.
\end{abstract}

Keywords: abrasion, accretion, NSM, EPR, LRR

\section{PENDAHULUAN}

Wilayah pesisir di Kabupaten Kendal merupakan salah satu wilayah pesisir Pantai Utara Pulau Jawa yang dimanfaatkan sebagai pusat kegiatan manusia. Beberapa kegiatan manusia yang berlangsung yakni pembangunan pusat pemerintahan, perdagangan, pemukiman, industri, pelabuhan, pertambakan, pertanian, perikanan, dan pariwisata di wilayah ini. Tingginya intensitas kegiatan di wilayah pesisir di Kabupaten Kendal memberikan dampak berupa peningkatan kebutuhan sumberdaya lahan dan degradasi lingkungan di wilayah pesisir. Permasalahan yang sekarang ini dialami oleh Kabupaten Kendal adalah adanya perubahan garis pantai yang dipicu oleh beberapa faktor diantaranya pengaruh angin muson, perubahan iklim, dan adanya abrasi serta akresi di wilayah pesisir.

Perubahan garis pantai di Pantai Utara Pulau Jawa berlangsung sangat dinamis. Perubahan garis pantai ini dipicu oleh adanya abrasi dan akresi. Proses erosi garis pantai meru- pakan pemunduran garis pantai ke daratan (Stephenson, 2016). Proses erosi pantai menurut (Sunarto dkk, 2014) terdiri dari empat jenis yaitu hydraulic impact, attrition, abrasion, dan solution. Proses abrasi pantai merupakan salah satu proses erosi pantai yang banyak terjadi di berbagai pantai di dunia (Kurniawan, 2018). Abrasi pantai dapat diartikan sebagai degradasi garis pantai akibat bekerja proses fisik seperti angin, arus, hujan, gelombang, serta aktivitas manusia.

Proses abrasi dan akresi berdampak kepada peningkatan dan penurunan luas wilayah daratan. Proses abrasi menyebabkan wilayah daratan terkikis atau tererosi sehingga wilayah daratan semakin berkurang (Istiqomah dkk, 2016). Fenomena penurunan luas wilayah daratan banyak ditemukan di pesisir timur Kabupaten Kendal yang menyebabkan beberapa kawasan perikanan tambak tenggelam Kurniawan (2018). Proses akresi merupakan proses peningkatan luas wilayah daratan akibat adanya pengendapan mate- 
rial sedimen. Fenomena bertambahnya luas wilayah daratan di Kabupaten Kendal ditemui di muara Sungai Bodri yang membentuk Delta Bodri. Pembentukan Delta Bodri ini disebabkan oleh tingginya laju sedimentasi di wilayah hilir (Sanjoto dkk, 2019). Adanya peningkatan dan penurunan wilayah daratan tentu akan berdampak kepada dinamika perubahan garis pantai di Kabupaten Kendal.

Pemantauan perubahan garis pantai akibat adanya abrasi dan akresi penting dilakukan sebagai salah satu upaya untuk menjaga batas wilayah lautan yang berkaitan erat dengan kepemilikan sumberdaya laut di suatu daerah. Pemantauan perubahan garis pantai dapat dilakukan dengan menggunakan pengamatan dengan memanfaatkan teknologi penginderaan jauh maupun dengan melakukan survei langsung di lapangan dengan mengukur garis pantai. Penginderaan jauh merupakan teknik atau seni yang memanfaatkan gelombang elektromagnetik untuk menangkap obyek kenampakan di permukaan bumi. Teknologi ini mampu menghasilkan citra penginderaan jauh. Perubahan garis pantai dapat diukur dan diamati secara detail dengan menganalisa citra secara multitemporal oleh pakar ahli (Winarso dkk, 2009).

Tujuan dari penelitian terkait dinamika perubahan garis pantai di Kabupaten Kendal tahun 2000-2020 yakni untuk (1) memetakan perubahan garis pantai di Kabupaten Kendal tahun 2000, 2005, 2010, 2015, dan 2020 dengan menggunakan metode band ratio, (2) menganalisis abrasi tertinggi serta akresi tertinggi di wilayah pesisir Kabupaten Kendal dengan metode Net Shoreline Movement (NSM), End Point Rate (EPR), dan Linear Regression Rate-of-Change (LRR), (3) menganalisis dampak dari perubahan garis pantai dan upaya mitigasi yang dapat dilakukan dalam menangani perubahan garis pantai melalui wawancara mendalam dengan pemerintah Kabupaten Kendal.

\section{METODE PENELITIAN}

Lokasi penelitian berada di wilayah pesisir Kabupaten Kendal yang secara geografis terletak di $109^{\circ} 40^{\prime}$ BT $-119^{\circ} 8^{\prime}$ BT dan 6 $6^{\circ}$ ' LS - 7²4' LS. Kabupaten Kendal berbatasan dengan Laut Jawa di bagian utara, Kota Semarang di bagian timur, Kabupaten Semarang dan Kabupaten Temanggung di bagian selatan, serta Kabupaten Batang di bagian barat. Lokasinya yang berbatasan langsung dengan Laut Jawa menyebabkan Kabupaten Kendal memiliki wilayah pesisir yang selalu berubah. Gelombang Laut Jawa yang cenderung tidak besar disertai bermuaranya material sedimen dari hulu menyebabkan material ini terdeposisi di pesisir Utara Jawa dan membentuk delta (Marfai dkk, 2016). Secara umum, terdapat 7 kecamatan di Kabupaten Kendal yang memiliki wilayah pesisir diantaranya Kecamatan Rowosari, Kecamatan Kangkung, Kecamatan Cepiring, Kecamatan Patebon, Kecamatan Kota Kendal, Kecamatan Brangsong, dan Kecamatan Kaliwungu (Gambar 1).

Data yang digunakan dalam penelitian ini terdiri atas data primer dan data sekunder. Pengumpulan data primer dilakukan melalui wawancara mendalam dengan informan ahli yakni Dinas Pekerjaan Umum dan Penataan Ruang (DPUPR) Kabupaten Kendal. Informan dalam wawancara mendalam ditentukan secara purposif, dimana informan yang dipilih dinilai relevan dan mampu menjawab tujuan penelitian. Data yang dikumpulkan melalui wawancara mendalam berupa data kualitatif terkait dengan dampak dari terjadinya perubahan garis pantai serta tindakan yang telah dil- akukan dalam merespon perubahan garis pantai. Data sekunder berupa citra Landsat 7 ETM+ tahun 2000, 2005, 2010, 2015, dan 2020 sebagai sumber data garis pantai wilayah kajian yang diperoleh dari www.earthexplorer.usgs.gov. Citra satelit yang digunakan merupakan citra dengan tutupan awan yang paling sedikit. Pemilihan tahun analisis dengan rentan skala 5 tahun karena berdasarkan pengamatan dari citra satelit, pesisir utara Kabupaten Kendal berubah sangat dinamis dalam jangka waktu yang singkat. Menurut Leo van Rijin (2010), skala waktu pemetaan menengah digunakan untuk memetakan perubahan garis pantai yang bisa mencapai 100 meter dalam periode 10 tahun.

Pengolahan data garis pantai dilakukan dengan memanfaatkan Citra Landsat 7 ETM+. Citra tersebut diolah menggunakan perangkat lunak ENVI untuk memperoleh data garis pantai di wilayah kepesisiran Kabupaten Kendal. Teknik yang digunakan untuk ekstraksi atau penentuan garis pantai di wilayah kajian adalah Hystogram Threshold. Marfai dan Rosaji (2018) menjelaskan bahwa teknik ini merupakan salah satu pixel based method yang dapat mendeteksi garis pantai dari citra multispektral. Metode ini dapat memisahkan antara lahan dan badan air (laut) secara cepat dan akurat. Teknik hystogram threshold ini dapat dilakukan berdasarkan single band, band ratio, NDVI, dan Principal Componentband.

Metode yang digunakan untuk memisahkan antara wilayah daratan dengan badan air (laut) pada penelitian ini adalah metode band ratio yang memanfaatkan band NearInfrared dan Green. Penggunaan dua band ini dilakukan karena ekstraksi garis pantai menggunakan single band (NIR) memiliki kelemahan, diantaranya adalah sulit untuk mengidentifikasi daerah yang tertutup oleh vegetasi. Oleh karena itu, band Green turut dipertimbangkan dalam ekstraksi garis pantai agar batas darat-air yang tertutup oleh vegetasi dapat diidentifikasi (Dewi, 2019). Adapaun formula band ratio yang digunakan dalam penelitian ini diuraikan pada persamaan (1):

$$
\text { Band Ratio }=\frac{\text { Band } 4(\text { Near }- \text { Infrared })}{\text { Band } 2(\text { Green })}
$$

Analisis perubahan garis pantai menggunakan Digital Shoreline Analysis System (DSAS) dengan dilakukan smoothing 2500, interval 50, dan jumlah transek 621. Proses koreksi

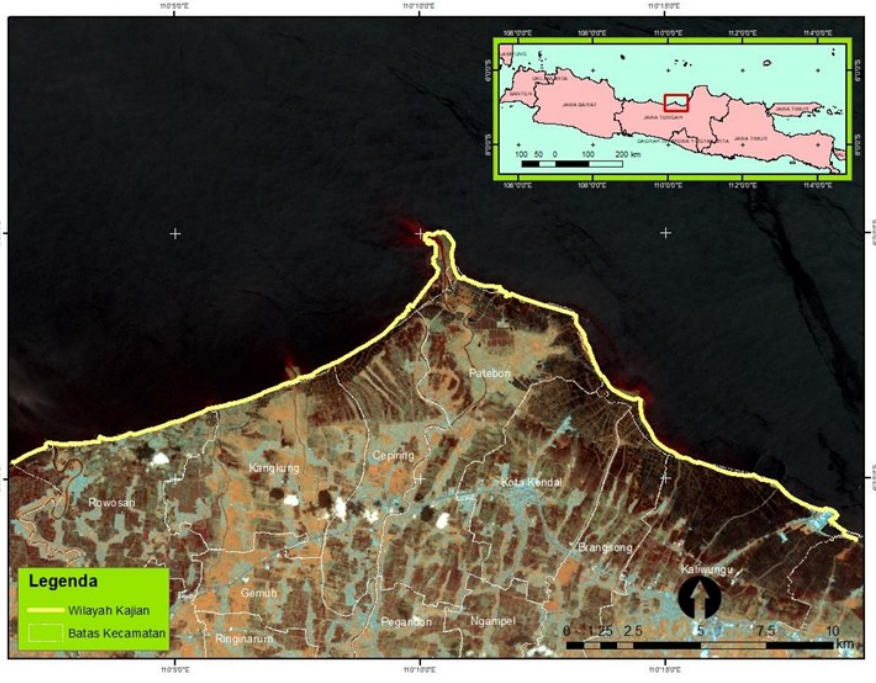

Gambar 1. Peta Wilayah Kajian 
hanya dilakukan dengan melakukan koreksi radiometrik dan geometrik pada saat pengolahan peta. Secara umum penelian ini tidak melakukan koreksi dengan garis pasang surut karena penelitian ini menghiraukan adanya pengaruh hidrooseanografi.

Digital Shoreline Analysis System (DSAS) merupakan perangkat lunak tambahan dalam ArcGIS yang dapat digunakan untuk menghitung perubahan garis pantai secara statistik dan berbasis geospasial berdasarkan periode waktu tertentu (Himmelstoss dkk, 2018). Metode statistik yang digunakan untuk menganalisis perubahan garis pantai di Kabupaten Kendal yakni Net Shoreline Movement (NSM), End Point Rate (EPR), dan Linear Regression Rate-of-Change (LRR). Metode NSM digunakan untuk mengetahui perbedaan jarak garis pantai yang telama dan terkini (Muskananfola dan Febrianto, 2020). EPR merupakan perbedaan jarak garis pantai yang telama dan terkini dibagi dengan waktu periode tersebut (Himmelstoss dkk, 2018). LRR merupakan analisis statistik tingkat perubahan yang bisa ditentukan dengan garis regresi least-square terhadap titik acuan dengan transek dengan menggunakan regresi linear (Himmelstoss dkk, 2018). Detail langkah pengolahan dan analisis data dapat dilihat pada diagram alir penelitian (Gambar 2).

\section{HASIL DAN PEMBAHASAN}

Hasil ekstraksi garis pantai di Kabupaten Kendal dianalisis berdasarkan tahun pengamatan yang dilakukan yaitu tahun 2000 sampai tahun 2020. Berdasarkan peta perubahan garis (Gambar 3) pantai serta grafik LRR (Gambar 4) dapat diketahui perubahan garis pantai Kabupaten Kendal. Kecamatan Rowosari dan Cepiring merupakan kecamatan yang laju perubahan garis pantainya paling stabil dibandingkan dengan kecamatan-kecamatan lainnya. Hal ini diketahui berdasarkan garis transek di Kecamatan Rowosari tidak adanya perubahan, dan untuk Kecamatan Cepiring walaupun mengalami akresi dan juga abrasi akan tetapi proses tersebut berjalan secara seimbang yaitu dengan besarnya proses abrasi hampir sama dengan besarnya proses akresi yang terjadi. Kondisi perubahan garis pantai yang cenderung stabil terjadi karena adanya proses morfodinamika pesisir yang dikontrol oleh tenaga yang berasal dari laut (oseanografi) dan daratnya seimbang (Richard \& Sunarto, 2015). Tabel 1 menunjukkan rata-rata laju perubahan garis pantai untuk Kecamatan Rowosari sebesar 0,07 m/tahun dan Kecamatan Cepiring sebesar 0,19 m/tahun.

Hasil dari analisis laju perubahan garis pantai masingmasing perubahan garis pantai tiap kecamatan di Kabupaten Kendal dapat diketahui melalui analisis garis transek dengan metode LRR. Berdasarkan Tabel 1, perubahan garis pantai di Kecamatan Rowosari dikontrol oleh proses abrasi dan akresi dimana besarnya abrasi mencapai 4,56 m/tahun dan akresi sebesar 5,84 m/tahun. Perubahan garis pantai di Kecamatan Rowosari berdasarkan nilai maksimal kejadian abrasi dan akresi didapatkan rata-rata laju perubahan garis pantai sebesar 0,07 m/tahun, angka ini jika dibandingkan dengan kecamatan-kecamatan yang lainnya nilainya yang paling kecil. Sehingga data tersebut menunjukkan bahwa perubahan garis pantai di Kecamatan Rowosari yang paling stabil dibandingkan dengan kecamatan-kecamatan lainnya.

Hasil dari analisis laju perubahan garis pantai masingmasing perubahan garis pantai tiap kecamatan di Kabupaten Kecamatan Rowosari dikontrol oleh proses abrasi dan akresi

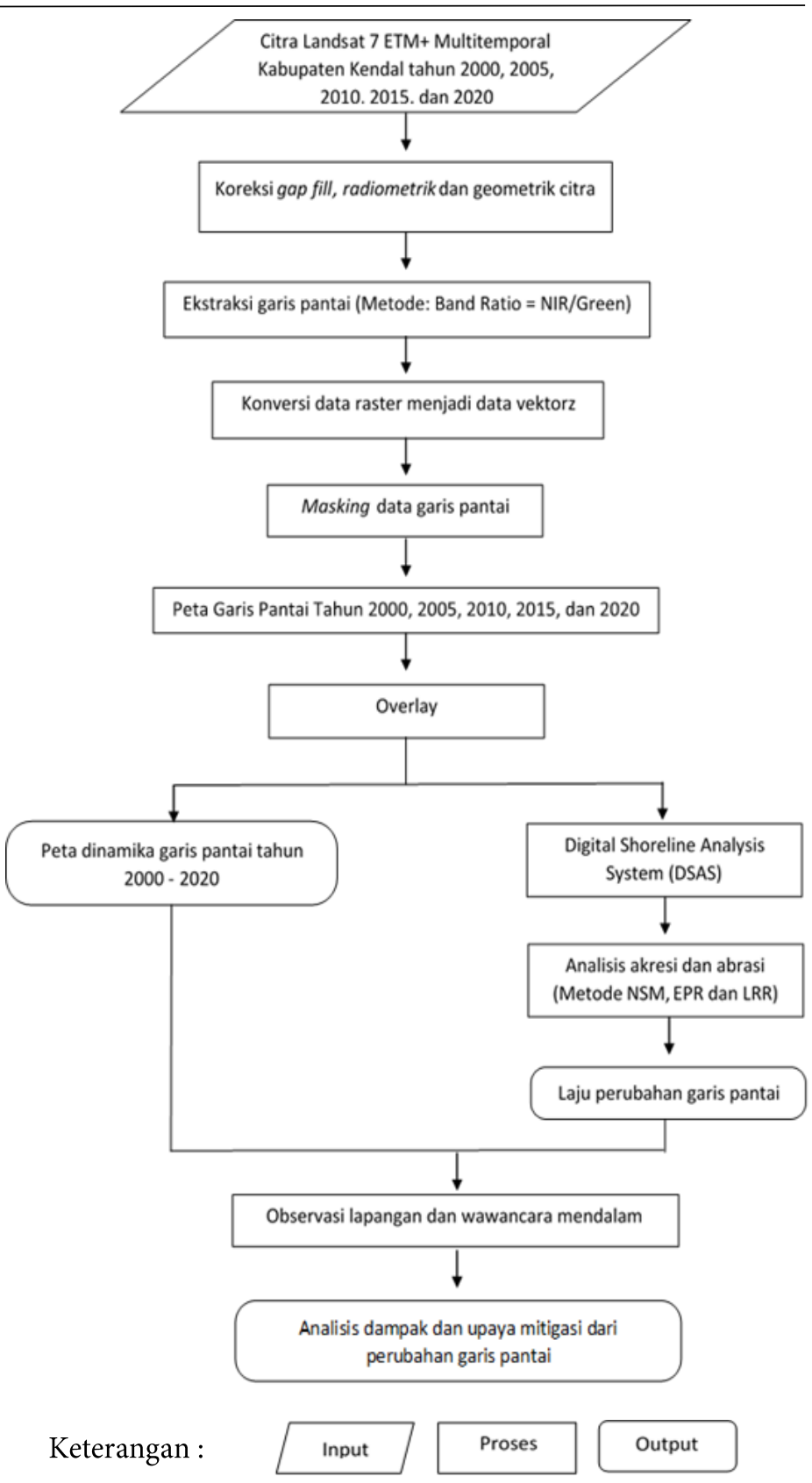

Gambar 2. Diagram Alir Penelitian

dimana besarnya abrasi mencapai 4,56 m/tahun dan akresi sebesar 5,84 m/tahun. Perubahan garis pantai di Kecamatan Rowosari berdasarkan nilai maksimal kejadian abrasi dan akresi didapatkan rata-rata laju perubahaKendal dapat diketahui melalui analisis garis transek dengan metode LRR. Berdasarkan Tabel 1, perubahan garis pantai di n garis pantai sebesar 0,07 m/tahun, angka ini jika dibandingkan dengan kecamatan-kecamatan yang lainnya nilainya yang paling kecil. Sehingga data tersebut menunjukkan bahwa perubahan garis pantai di Kecamatan Rowosari yang paling stabil dibandingkan dengan kecamatan-kecamatan lainnya.

Perubahan garis pantai di Kecamatan Kangkung berdasarkan analisis garis transek metode LRR didominasi oleh proses akresi, akan tetapi proses abrasi juga masih terjadi walaupun nilainya sangat kecil. Nilai maksimal laju perubahan garis pantai di Kecamatan Kangkung pada proses abrasi mencapai $0,59 \mathrm{~m} /$ tahun dan akresi mencapai $11,86 \mathrm{~m} /$ tahun, serta perubahan garis pantai rata-rata sebesar 3,09 m/ tahun (Tabel 1). Kondisi perubahan garis pantai di Kecamatan Cepiring mirip dengan Kecamatan Rowosari yaitu 

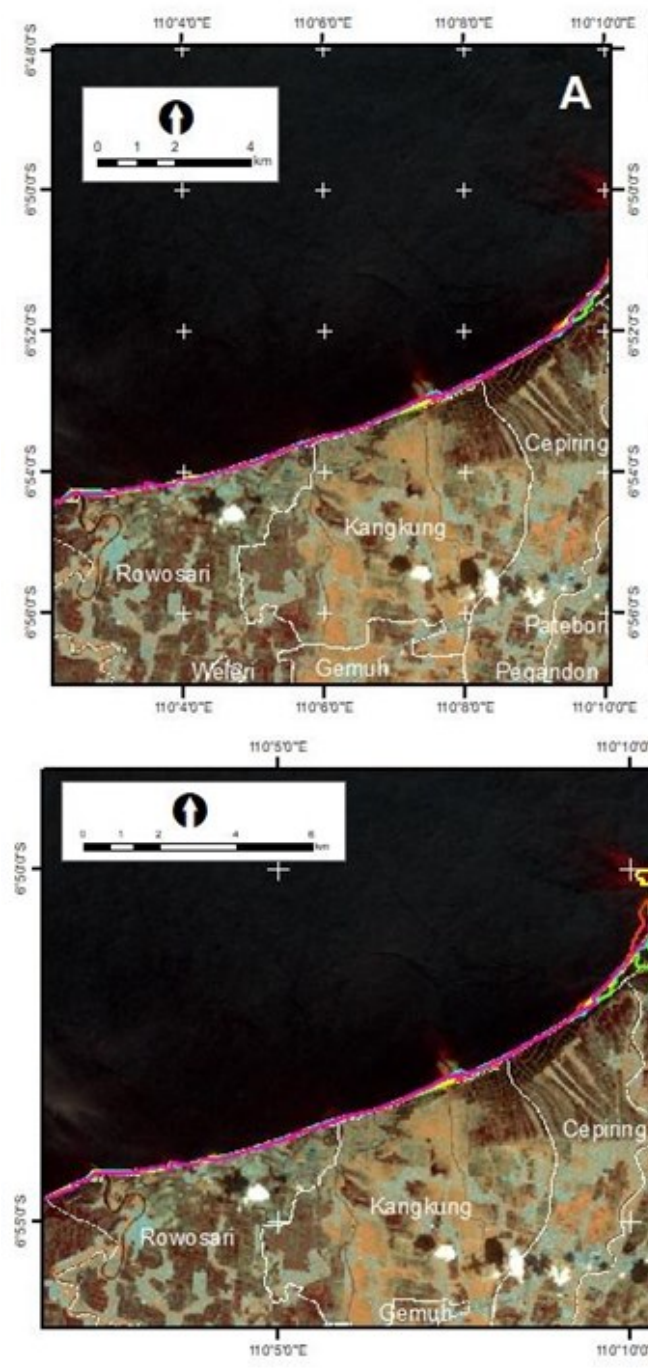

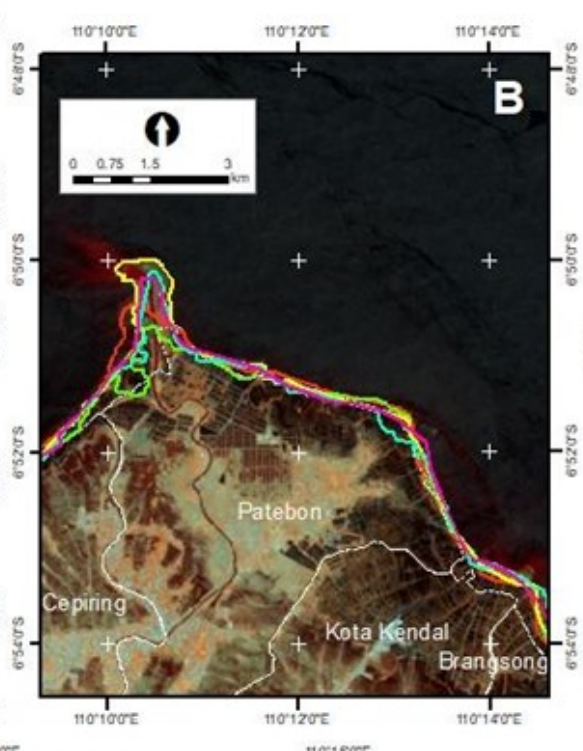

Hetrome

noroore
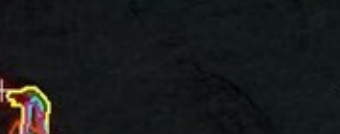

$+$

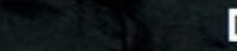

$+$

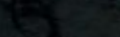

D
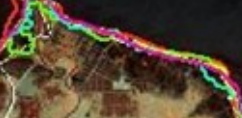

r.

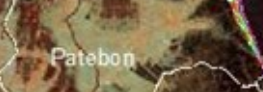

(5)

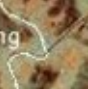

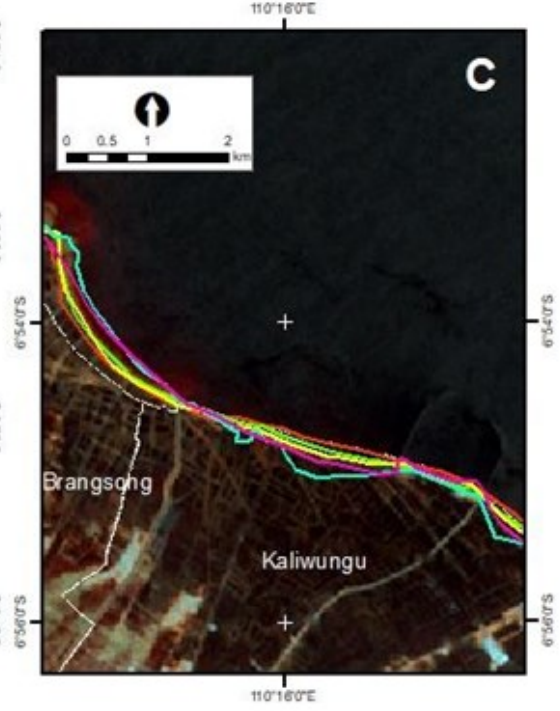

Legenda

Garis Pantai

- 2020

- 2015

2010

$-2005$

2000

Gambar 3. Dinamika Garis Pantai Kabupaten Kendal (A) Kecamatan Rowosari, Kecamatan Kangkung, dan Kecamatan Cepiring yang cenderung tidak mengalami perubahan garis pantai (stabil) (B) Delta Bodri di Kecamatan Patebon yang cenderung mengalami akresi dan abrasi (dinamis) (C) Kecamatan Brangsang dan Kaliwungu yang cenderung mengalami akresi (D) Perubahan Garis Pantai di Kabupaten Kendal Tahun 2000-2020

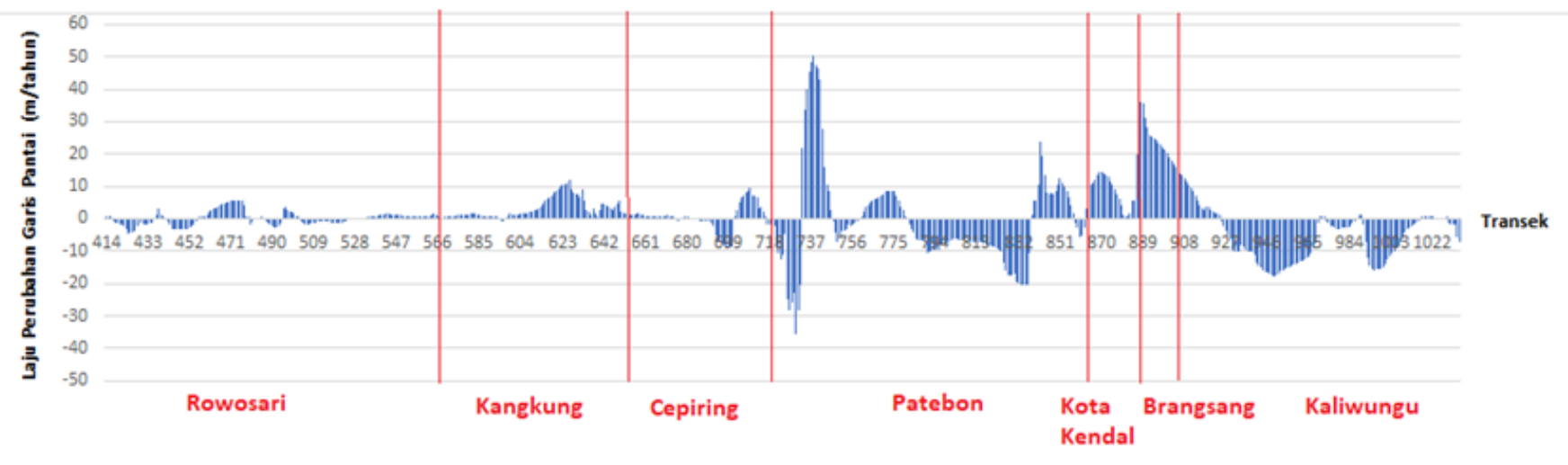

Gambar 4. Grafik Linear Regression Rate (LRR) laju perubahan garis pantai tahun 2000-2020

cenderung stabil dengan rata-rata laju perubahan garis pantai sebesar $0,19 \mathrm{~m} /$ tahun. Perubahan garis pantai yang stabil ini tidak menandakan tidak adanya proses abrasi dan akresi yang terjadi, tetapi kondisi yang stabil ini terjadi karena besarnya material yang terabrasi kurang lebih sama jumlahnya dengan material yang terakresi. Nilai maksimal perubahan garis pantai karena proses abrasi sebesar $8,77 \mathrm{~m} /$ tahun dan akibat proses akresi sebesar 9,55 m/tahun.

Nilai maksimal laju perubahan garis pantai Kecamatan Patebon terhadap proses abrasi sebesar $35,81 \mathrm{~m} / \mathrm{tahun}$ dan akibat proses akresi mengalami perubahan sebesar $50,09 \mathrm{~m} /$ tahun, dari data tersebut diketahui rata-rata laju perubahan 
garis pantai di Kecamatan Patebon sendiri sebesar 0,52 m/ tahun (Tabel 1). Kecamatan Patebon, jika dilihat pada dinamika garis pantai Kabupaten Kendal (Gambar 3) dan grafik LRR (Gambar 4) merupakan kecamatan dengan kondisi garis pantai yang paling dinamis, baik itu proses abrasi ataupun akresi. Hal ini telah cukup menandakan bahwa kecamatan tersebut memiliki perubahan garis pantai yang paling dinamis dibandingkan dengan kecamatan lainnya di Kabupaten Kendal selama 20 tahun terakhir.

Muara Sungai Bodri di Kecamatan Patebon terdeteksi sebagai wilayah yang paling intensif perubahan garis pantainya. Secara periodik, perubahan garis pantai di muara Sungai Bodri tidak memiliki pola tertentu, daerah ini terus mengalami perubahan dominansi antara proses abrasi dan akresi. Berdasarkan penelitian yang dilakukan Wardhana dan Susandi (2015) terkait penentuan awal musim di Jawa berbasis Downscaling CCAM. Perekaman pada tahun 2000 dan 2010 tergolong kedalam musim penghujan karena citra terekam pada rentang musim september - april, sedangkan perekaman pada tahun 2005, 2015, dan 2020 tergolong kedalam musim kemarau karena citra terekam pada rentang april - september. Hal ini menandakan terdapat kesesuaian antara perubahan garis pantai dengan pola musiman yang ada di Pulau Jawa. Terlihat pada Gambar 3, tahun 2010 telah terjadi perluasan daerah daratan yang sangat signifikan di Muara Bodri. Tentu fenomena ini terdapat peran musim penghujan yang menyebabkan terjadinya transportasi sedimen yang sangat besar di Sungai Bodri, sehingga kemudian terjadi deposisi material di Muara Bodri dan menyebabkan perluasan daerah daratan pada tahun 2010. Pada tahun tersebut terlihat bahwa kontrol daratan terhadap dinamika garis pantai lebih dominan dibandingkan dengan kontrol oseanografi. Sedangkan pada tahun 2005, 2015, dan 2020 terlihat bahwa kontrol oseanografi lebih dominan. Material yang tererosi dan terdeposisi oleh tenaga aliran sungai pada musim ini jauh lebih rendah dibandingkan pada saat musim hujan, sehingga kontrol oseanografi menyebabkan terjadinya proses abrasi di Muara Bodri. Kontrol oseanografi seperti pola gelombang, arus permukaan laut, pasang surut, serta kontrol darat seperti debit sungai menyebabkan terjadinya perubahan muara sungai (Sunarto, 2000).

Muara Sungai Bodri sejatinya merupakan daerah yang sangat rentan terhadap proses abrasi. Hal ini disebabkan oleh morfologi daerahnya yang menjorok ke arah laut (tanjung). Kondisi ini menurut Kurniawan (2018) berpotensi mendapatkan energi gelombang, pasang surut, dan arus (kontrol oseanografi) yang lebih tinggi dibandingkan dengan wilayah kepesisiran lainnya. Kondisi inilah yang menyebabkan terjadinya pengikisan wilayah darat pada periode 2000 2005 dan 2010 - 2020.

Muara Sungai Bodri pada periode tahun 2005 - 2010 mengalami proses akresi yang sangat dominan. Terlihat dari bertambahnya wilayah daratan pada periode tersebut. Lumbanbatu dan Hidayat (2007) menyatakan pada di muara Sungai Bodri pada periode tersebut terindikasi adanya dorongan tenaga runoff sungai yang besar, dengan volume dan tenaga yang besar pula. Proses ini sukses menjadikan material yang terbawa oleh aliran sungai tersedimentasi di muara sungai. Hal ini menandakan bahwa dalam proses morfodinamika pesisir, kontrol darat lebih dominan dibandingkan dengan kontrol oseanografi yang ada pada periode tersebut.

Laju perubahan garis pantai di Kota Kendal memiliki nilai maksimal untuk proses abrasi sebesar 5,88 m/tahun dan proses akresi sebesar 14,65 m/tahunnya, serta rata-rata laju perubahannya sebesar $7,11 \mathrm{~m} /$ tahun (Tabel 1). Perubahan garis pantai yang terjadi yaitu garis pantai mengalami kemunduran atau proses abrasi lebih sering terjadi dibandingkan dengan proses akresinya. Kecamatan Brangsang perubahan garis pantainya hanya mengalami proses akresi sehingga garis pantainya terus mengalami kemajuan (Gambar 3). Berdasarkan Tabel 1, Nilai maksimal laju perubahan pantai di Kecamatan Brangsang sebesar 35,89 m/tahun dan nilai minimumnya sebesar $0,17 \mathrm{~m} / \mathrm{tahun}$, dan rata-rata laju perubahan garis pantainya sebesar $20,50 \mathrm{~m} /$ tahun. Perubahan garis pantai di Kecamatan Kaliwungu proses abrasi terjadi lebih mendominasi sepanjang garis pantainya dibandingkan dengan proses akresi. Nilai maksimum untuk proses abrasi yang terjadi yaitu sebesar 17,98 m/tahun dan proses akresi sebesar 14,1 m/tahun. Rata-rata laju perubahan garis pantai di Kecamatan Kaliwungu sebesar 5.35 m/tahun dan perubahan yang terjadi ini garis pantai juga mengalami kemunduran atau abrasi sama seperti yang terjadi di Kecamatan Patebon dan Kota Kendal. Berdasarkan hasil penelitian Kurniawan (2018) dalam mengidentifikasi dinamika garis pantai di Muara Sungai Bodri dan Sungai Blorong dengan menggunakan citra Landsat 5 , besarnya rata-rata LRR yang terjadi di wilayah tersebut $3,33 \mathrm{~m} /$ tahun atau 1,8 $\mathrm{m} /$ tahun lebih tinggi dibandingkan dengan menggunakan citra landsat 7 ETM+. Perbedaan ini dapat dikarenakan berbagai faktor, diantaranya adalah media landsat yang berbeda dan luas daerah penelitian yang berbeda. Hal ini menandakan bahwa dengan metode yang sama namun dengan media dan luasan yang berbeda, dapat menghasilkan nilai statistik yang berbeda pula.

Secara umum wilayah kepesisiran Kabupaten Kendal mengalami dinamika garis pantai yang cukup signifikan. Kontrol oseanografi dan darat sama-sama memiliki andil yang dominan dan tak berpola di daerah penelitian. Aktivitas manusia yang intensif dengan ditandai hadirnya kegiatan industri, permukiman, dan wisata di daerah tersebut turut mempengaruhi dinamika dan kompleksitas wilayah kepesisiran di bagian utara Jawa Tengah, termasuk didalamnya Kabupaten Kendal (Marfai dkk., 2015). Tingginya aktivitas manusia ini tidak lain dikarenakan topografi wilayah yang umumnya berupa dataran rendah dengan morfologi yang cenderung datar hingga landai (Marfai dkk, 2016). Daerah penelitian juga memiliki litologi daerah yang didominasi oleh batuan lempung pasiran dan pasir lempungan (Wahib, 1993). Aktivitas manusia, material yang cenderung mudah tertransportasi, ditambah dengan hadirnya aliran sungai dengan debit, tenaga, dan volume yang ada telah cukup berperan sebagai kontrol darat dalam dinamika garis pantai di Kabupaten Kendal. Sedangkan di sisi lain, karakteristik pasang surut, arus, serta gelombang Laut Jawa berperan sebagai kontrol oseanografi dalam perubahan garis pantai di daerah penelitian.

Nilai Net Shoreline Movement (NSM) garis pantai Kabupaten Kendal selama periode 2000-2020 (Tabel 2) menunjukkan nilai abrasi maksimum (1.030,32 meter) yang lebih tinggi daripada akresinya (684,54 meter). Nilai maksimum tersebut didapatkan dari beberapa transek yang telah dibuat dengan interval 50 meter di sepanjang garis pantai Kabupaten Kendal. Nilai NSM pada setiap transek ini menggambarkan perubahan posisi garis pantai pada periode waktu 20 tahun. Setelah 20 tahun, garis pantai Kabupaten Kendal rata-rata 
mengalami pemunduran garis pantai ke arah darat (abrasi) sebesar 1,41 meter. Hasil tersebut didapatkan hanya dengan membandingkan kondisi garis pantai tahun 2000 dengan garis pantai 2020 dan mengabaikan perubahan yang mungkin terjadi antara periode tahun tersebut. Penelitian sebelumnya oleh Kurniawan (2018) mengungkapkan bahwa sepanjang pesisir muara Sungai Sibeo dan Blorong selama 1990-2017 telah terjadi akresi maksimum sebesar 1.763,29 meter dan abrasi maksimum sebesar 792,14 meter. Hal tersebut berbeda dengan hasil statistik NSM yang telah dilakukan yang justru lebih dominan terjadi abrasi. Perbedaan tersebut menunjukkan bahwa garis pantai utara Pulau Jawa sangat dinamis.

Perubahan posisi garis pantai Kabupaten Kendal pada periode yang lebih pendek dianalisis dalam kurun waktu 5 tahunan. Sebagian besar pemunduran garis pantai pada transek terjadi di periode 2000-2005 dan 2010-2015 dengan rata-rata pemunduran garis pantai berturut-turut sebesar 36,59 meter dan 53,39 meter (Tabel 2). Pemajuan garis pantai ke arah laut (akresi) pada transek sebagian besar terjadi di periode 2005-2010 dan 2015-2020 dengan rata-rata pemajuan garis pantai berturut-turut sebesar 67,15 meter dan 23,49 meter. Proses pemunduran dan pemajuan garis pantai ini berdampak pada penambahan dan pengurangan luas wilayah (Tabel 2) terlihat bahwa pada tahun 2000-2005 dan 2010-2015 Kabupaten Kendal cenderung mengalami penurunan luas wilayah sedangkan pada tahun 2005-2010 dan 2015-2020 cenderung mengalami peningkatan luas wilayah. Pola tersebut mengikuti proses yang terjadi dominan pada kurun waktu tersebut. Periode 2005-2010 berdasarkan Tabel 2 menjadi periode yang dominan mengalami pemajuan garis pantai karena pada transek terjadi dominan akresi dengan nilai maksimum mencapai 2527,14 meter terutama di muara Sungai Bodri. Periode ini telah mengubah bentuk delta Bodri dari yang semula berbentuk cenderung cuspate (berbentuk huruf $\mathrm{v}$ terbalik) menjadi elongated (memanjang). Menurut Galloway (1975) perubahan bentuk delta dapet disebabkan oleh besarnya energi sungai. Sebaliknya, periode 2010-2015 terjadi dominan pemunduran garis pantai karena terjadi abrasi dengan nilai maksimum 2018,98 meter ke arah darat terutama di sekitar muara Sungai Bodri dan pesisir Kaliwungu. Secara temporal, pola abrasi 5 tahunan mengalami peningkatan saat periode dominasi abrasi, sedangkan pola akresi 5 tahunan mengalami penurunan saat periode dominasi akresi. Pola inilah yang menjelaskan kecenderungan terjadinya proses pemunduran garis pantai ke arah darat setelah 20 tahun (2000-2020).
Kecenderungan pemunduran garis pantai (abrasi) tidak terjadi di seluruh pesisir Kabupaten Kendal. Beberapa wilayah terutama di sekitar muara sungai di Kabupaten Kendal terjadi pemajuan garis pantai (Kurniawan, 2018). Beberapa faktor yang mempengaruhi pemunduran garis pantai (abrasi) salah satunya ialah kenaikan muka air laut (Marfai, 2014). Berdasarkan publikasi oleh Kresteva dkk. (2014), rata-rata kenaikan muka air laut (MSL) di pesisir Kendal-Semarang selama 2004-2010 sebesar 9,44 cm/tahun. Kenaikan tersebut merupakan nilai kenaikan muka air laut total tanpa mempertimbangkan besarnya faktor penurunan muka tanah. Kenaikan muka air tanah tidak hanya disebabkan oleh perubahan iklim saja tetapi juga berbagai faktor lokal seperti besarnya pengambilan airtanah (Marfai, 2014). Salah satu indikasi adanya kenaikan muka air laut ialah terjadinya genangan rob dengan frekuensi yang semakin sering dan jangkauan yang lebih luas (Diposaptono dkk, 2009).

Laju perubahan garis pantai Kabupaten Kendal dapat diketahui dengan menggunakan metode End Point Rate (EPR). Laju perubahan garis pantai dengan metode EPR menggunakan data dua garis pantai dengan waktu yang berbeda. Metode EPR ini digunakan karena dapat menggambarkan laju perubahan garis pantai pada setiap periode perubahan (Kurniawan, 2018). Nilai laju perubahan garis pantai Kabupaten Kendal metode EPR didapatkan dari statistik hasil pengolahan Digital Shoreline Analysis System (DSAS) yang dapat dilihat pada Tabel 3. Nilai EPR dapat bernilai negatif yang berarti abrasi dan benilai positif yang berarti akresi (Mutaqin, 2017). Selama kurun waktu 20 tahun, dari tahun 2000 hingga tahun 2020, nilai laju perubahan garis pantai Kabupaten Kendal dengan metode EPR yaitu -0,07 m/ tahun. Hal ini berarti dalam kurun waktu 20 tahun, garis pantai Kabupaten Kendal mengalami abrasi atau pemunduran garis pantai dengan laju perubahan setiap tahunnya 0,07 meter. Hasil ini hanya menggunakan dua garis pantai yaitu garis pantai tahun 2000 dan 2020, sehingga tidak mempertimbangkan perubahan dalam yang terjadi pada tahun-tahun diantara 20 tahun tersebut.

Laju perubahan garis pantai Kabupaten Kendal juga dilakukan per periode dengan satu periode memiliki kurun waktu lima tahun. Periode tahun 2000-2005, nilai laju perubahan garis pantai metode EPR Kabupaten Kendal sebesar $8,27 \mathrm{~m} /$ tahun (Tabel 3). Hal tersebut berarti, selama kurun waktu tersebut, rata-rata garis pantai di Kabupaten Kendal mengalami pemunduran atau abrasi dengan laju abrasi 8,27 meter setiap tahunnya. Kabupaten Kendal terletak di pesisir Utara Jawa sehingga memiliki kawasan pantai yang dinamis.

Tabel 2. Nilai tertinggi dan terendah dari abrasi dan akresi di Kabupaten Kendal dengan metode Net Shoreline Movement (NSM)

\begin{tabular}{|c|c|c|c|c|c|c|}
\hline \multirow[t]{2}{*}{ Periode } & \multicolumn{2}{|c|}{ Abrasi (m) } & \multicolumn{2}{|c|}{ Akresi (m) } & \multirow{2}{*}{$\begin{array}{c}\text { Rata-rata } \\
\pm \operatorname{STDEV~}(\mathrm{m})\end{array}$} & \multirow{2}{*}{$\begin{array}{l}\text { Rata-rata perubahan luas } \\
\text { wilayah } \pm \operatorname{STDEV~}\left(\mathrm{m}^{2}\right)\end{array}$} \\
\hline & Tertinggi & Terendah & Tertinggi & Terendah & & \\
\hline $2000-2005$ & $1.703,56$ & 0,22 & 352,59 & 0,10 & $-36,59 \pm 176,64$ & $-27.498,03 \pm 213.250,01$ \\
\hline 2005-2010 & 179,91 & 0,08 & $2.527,14$ & 0,06 & $67,15 \pm 330,53$ & $17.377,47 \pm 122.726,47$ \\
\hline 2010-2015 & $2.018,98$ & 0,38 & 708,77 & 0,13 & $-53,39 \pm 282,03$ & $-17.218,79 \pm 138.190,60$ \\
\hline 2015-2020 & 478,29 & 0,02 & 910,36 & 0,15 & $23,49 \pm 101,67$ & $12.185,77 \pm 60.854,10$ \\
\hline $2000-2020$ & $1.030,32$ & & 684,54 & & $-1,41 \pm 180,77$ & \\
\hline
\end{tabular}


Perubahan garis pantai ada yang mengalami abrasi dan ada pula yang mengalami akresi atau kemajuan garis pantai, seperti pada periode tahun 2005-2010. Periode tersebut memiliki nilai rata-rata EPR sebesar $12,16 \mathrm{~m} /$ tahun. Hal ini berarti, perubahan yang terjadi pada periode ini yaitu penambahan garis pantai atau akresi dengan laju rata-ratanya 12,16 meter setiap tahunnya. Periode tahun 2010 hingga 2015, nilai EPR pantai Kabupaten Kendal sebesar -11,83 m/tahun. Hal tersebut berarti, pantai Kendal pada periode ini mengalami abrasi dengan rata-rata laju abrasinya 11,83 meter setiap tahunnya. Periode tahun 2015-2020, nilai EPR sebesar 4,50 m/tahun. Garis pantai Kabupaten Kendal mengalami penambahan 4,50 meter setiap tahunnya pada tahun 2015-2020.

Laju perubahan garis pantai Kabupaten Kendal selama kurun waktu 20 tahun mengalami naik turun selama empat periode (Tabel 3). Penambahan garis pantai atau akresi terjadi pada periode tahun 2005-2010 dan 2015-2020, sedangkan pengikisan pantai atau abrasi terjadi pada periode tahun 2000-2005 dan 2010-2015. Hal ini terjadi karena, perubahan garis pantai dipengaruhi oleh adanya proses-proses di sekitarnya. Akresi dapat disebabkan karena adanya proses sedimentasi dari arah darat maupun laut yang berakibat pada bertambahnya garis pantai. Sedimentasi dari arah darat dapat disebabkan karena adanya perubahan penggunaan lahan dan erosi yang tidak terkontrol di area hulu sehingga menyebabkan adanya penambahan garis pantai (Marfai dkk, 2008). Abrasi dapat terjadi karena dipengaruhi oleh proses alami seperti pergerakan sedimen, gelombang karena angin, pasang surut air laut, dan naiknya permukaan air laut karena adanya pemanasan global (Marfai, 2011). Selain itu, material sedimen, perlindungan pantai, dan penggunaan lahan juga dapat mempengaruhi erosi pantai (Mutaqin, 2017).

Nilai laju perubahan garis pantai di Kabupaten Kendal termasuk ke dalam proses akresi dan abrasi yang tinggi jika dilihat dari besarnya nilai EPR di wilayah tersebut. Hal ini karena, nilai EPR menunjukkan nilai yang lebih dari 2 baik yang positif (akresi) maupun negatif (abrasi). Berdasarkan klasifikasi EPR yang dikemukakan oleh Nathesan dkk. (2015) nilai EPR yang lebih dari $-2 \mathrm{~m} /$ tahun dapat diklasifikasikan garis pantai yang terabrasi sangat tinggi dan nilai EPR yang lebih dari $2 \mathrm{~m} /$ tahun diklasifikasikan terakresi sangat tinggi.

Perubahan garis pantai langsung berdampak pada perubahan penggunaan lahan akibat bertambah atau berkurangnya luas daratan. Perubahan penggunaan lahan tersebut diikuti dengan perubahan ekosistem atau bahkan hilangnya suatu habitat dalam ekosistem di sekitarnya. Akresi pantai jika ditinjau dari aspek strategis membawa dampak positif yaitu bertambahnya luasan suatu kawasan. Akresi pantai juga dapat berdampak buruk yaitu pendangkalan yang terjadi dapat mengganggu navigasi dan alur pelayaran kapal. Menurut (Fajrin dkk, 2016), perubahan garis pantai berupa abrasi juga dapat berdampak pada masyarakat sehingga menyebabkan tergenangnya tempat tinggal oleh air laut hingga mempengaruhi kondisi sosial yang terdapat di sekitar pantai.

Garis pantai Kabupaten Kendal seperti yang terdapat dalam Gambar 3 mengalami perubahan dalam kurun waktu 20 tahun terakhir, dimana terdapat perbedaan jenis perubahan garis pantai di setiap lokasi. Daerah rawan abrasi di utara jawa tengah terdapat pada pantai yang memiliki jenis tipologi pantai berlumpur. Sebagian besar Pesisir Kabupaten Kendal Memiliki tipologi berlumpur, dimana pesisir dengan tipologi berlumpur sering dinilai tidak menguntungkan secara ekonomi (lahan marginal) sehingga pemanfaatan lahan
Tabel 3. Nilai rata-rata End Point Rate (EPR)

\begin{tabular}{rr}
\hline Periode & End Point Rate (m/tahun) \\
\hline $2000-2005$ & $-8, .27$ \\
$2005-2010$ & 12,16 \\
$2010-2015$ & $-11,83$ \\
$2015-2020$ & 4,50 \\
$2000-2020$ & $-0,07$ \\
\hline
\end{tabular}

terbatas (Mahendra dkk, 2017). Menurut Arief dkk. (2011), abrasi dan ancamannya semakin meluas dan mulai merambah ke rumah warga. Berbeda dengan abrasi, majunya garis pantai (akresi) yang secara umum terjadi akibat proses sedimentasi sungai banyak yang difungsikan menjadi lahan tambak. Abrasi dan akresi di wilayah pesisir timur Kabupaten Kendal juga disebabkan oleh tingginya pemanfaatan lahan dan aktivitas masyarakat di wilayah pesisir timur. Hal ini ditunjukkan dari tingginya pemanfaatan wilayah pesisir sebagai tambak dan juga pelabuhan (Seno, 2020).

Menurut Hazazi dkk. (2019), perubahan garis pantai yang terjadi di Kabupaten Kendal berhubungan dengan kerapatan mangrove, dimana semakin meningkat atau bertambahnya luas daratan (akresi) maka kerapatan mangrove yang digambarkan dengan nilai NDVI (Normalized Difference Vegetation Index) akan semakin tinggi dan sebaliknya. Ekosistem mangrove tidak dapat tumbuh secara baik di berbagai jenis tipologi pesisir. Ekosistem mangrove berkembang dengan baik pada lokasi yang terlindung dari gelombang laut serta terdapat sedimen dari sungai dan laut yang terendapkan sehingga membentuk dataran lumpur pasang surut yang banyak terdapat di pesisir Kabupaten Kendal (Mahendra dkk, 2017). Apabila dikelola dengan baik, ekosistem hutan mangrove dapat memberikan keuntungan dimana ekosistem hutan mangrove memiliki fungsi yang sangat kompleks diantaranya: segi fisik, ekologi, ekonomi dan sosial budaya (Hazazi dkk, 2019).

Aktivitas manusia selain terdampak oleh abrasi dan akresi, juga menyebabkan adanya abrasi dan akresi itu sendiri. Abrasi dan akresi di wilayah pesisir timur Kabupaten Kendal banyak disebabkan oleh tingginya pemanfaatan lahan dan aktivitas masyarakat. Hal ini ditunjukkan dari dari tingginya pemanfaatan wilayah pesisir sebagai tambak, kawasan industri dan juga pelabuhan. Tingginya aktivitas industri di pesisir timur Kabupaten Kendal juga berdampak pada pemanfaatan air yang berlebihan sehingga mempengaruhi kondisi air tanah, dimana menurut (Satrio dan Taufiq, 2015) sampel air di lokasi PT. Kayu Lapis Indonesia di Kec. Kaliwungu, Kabupaten Kendal mengalami intrusi air laut.

Pemanfaatan lahan bagi kepentingan industri, pelabuhan, dan pembangkit listrik memang banyak dilakukan di pesisir utara Pulau Jawa melalui proses reklamasi pantai sehingga menambah luas daratan (Setyawan \& Winarno, 2006). Namun, pemanfaatan lahan di bagian timur Kabupaten Kendal sebagai kawasan industri dan pelabuhan tidak melalui reklamasi pantai. Pengurukan tanah di pesisir Kabupaten Kendal hanya terbatas, bersifat mikro oleh masyarakat yang la- 
hannya terdampak oleh abrasi.

Kegiatan mitigasi untuk perubahan garis pantai di Kabupaten Kendal dilakukan dengan dua metode yaitu soft mitigation dan hard mitigation (Seno, 2020). Metode soft mitigation menggunakan unsur alam misalnya penanaman mangrove dan hard mitigation melalui pembangunan infrastruktur seperti talud, breakwater, maupun tanggul pantai (Hausmann, 2019). Upaya yang dilakukan dengan soft mitigation di Kabupaten Kendal berdasarkan sistem EcosystemBased Disaster Risk Reduction (Eco-DRR) dengan membentuk penanaman kembali mangrove sebagai upaya pengurangan erosi pantai. Hutan mangrove dapat befungsi sebagai pemecah gelombang sekaligus habitat bagi biota pesisir. Selain itu, mangrove juga dapat memberikan manfaat untuk kegiatan ekonomi masyarakat disekitarnya (Indarsih \& Masruri, 2019). Rehabilitasi mangrove merupakan salah satu program prioritas nasional dari Kementerian Lingkungan Hidup dan Kehutanan. Kegiatan tersebut diawali di Kabupaten Rembang sejak tahun 2000 dan berkembang pada tahun 2015 kegiatan dipusatkan di kabupaten lain termasuk Kabupaten Kendal (Solihuddin dkk, 2019). Penelitian terkait pengaruh keberadaan mangrove di Kabupaten Kendal terhadap perubahan garis pantai pernah dilakukan pada tahun 2019. Penelitian tersebut menyatakan terdapat penambahan luas mangrove pada 7 kecamatan di pesisir Kabupaten Kendal dari tahun 2014-2018. Hasil penelitiannya yaitu terdapat hubungan positif antara nilai indeks vegetasi dengan penambahan garis pantai, sehingga semakin luas hutan mangrove tingkat akresi semakin tinggi (Hazazi dkk, 2019).

Berdasarkan dokumen Rencana Terpadu dan Program Investasi Infrastruktur Jangka Menengah (RPI2JM) tahun 2016-2020 yang disusun oleh Bidang Cipta Karya Kabupaten Kendal, dalam mencegah dan mitigasi terjadinya abrasi di pesisir Kendal dilakukan restorasi pembangunan talud/break water di wilayah permukiman, dan perumahan sepanjang Pantura terutama pada Kawasan sempadan pantai yang meliputi Sebagian Kecamatan Rowosari, Kangkung, Cepiring, Kendal, Brangsong, Patebon, dan Kaliwungu (Bidang Cipta Karya Kabupaten Kendal, 2020). Pembangunan infrastruktur pelindung pantai yang telah dilakukan oleh Kabupaten Kendal yaitu pembangunan breakwater pada bagian barat dan timur di perairan Pelabuhan Kaliwungu Kabupaten Kendal yang mulai beroperasi pada tahun 2019 mundur dari rencana awal pada tahun 2014. Berdasarkan penelitian yang dilakukan oleh Siregar, Handoyo dan Rifai tahun 2014 menyatakan sedimentasi di sekitar Pelabuhan sangat tinggi, dan bangunan pemecah ombak kurang berpengaruh terhadap laju sedimentasi di perairan. Keberadaan breakwater menghambat gelombang yang menyebabkan sulitnya sedimen dipindahkan (Siregar dkk, 2014).

Upaya mitigasi perubahan garis pantai di Kabupaten Kendal dilakukan secara bersinergi antara pemerintah provinsi, pemerintah kabupaten, serta dinas-dinas terkait. Peran serta masyarakat juga dibutuhkan dalam upaya pencegahan dampak negatif dari perubahan garis pantai, yang dikoordinasikan oleh Dinas Kelautan dan Perikanan, Dinas Lingkungan Hidup, dan Dinas Pekerjaan Umum dan Penataan Ruang Kota. Pemberdayaan dilakukan dengan sosialiasi untuk menambah wawasan masyarakat serta pembentukan kelompok-kelompok tani dengan programprogram yang berkaitan dengan upaya mempertahankan lahan agar tidak tererosi oleh air laut (Seno, 2020).

\section{KESIMPULAN}

Kecamatan Rowosari, Kecamatan Kangkung, dan Kecamatan Cepiring merupakan daerah yang cenderung stabil dan tidak mengalami perubahan garis pantai yang cukup signifikan selama periode tahun 2000-2020. Hal ini dibuktikan dengan laju abrasi dan akresi di wilayah tersebut yang tidak terlalu besar. Kecamatan Patebon merupakan kecamatan yang mengalami proses abrasi dan akresi paling dinamis karena daerah ini merupakan hilir dari Sungai Bodri yang merupakan sungai yang membawa material sedimen. Kota Kendal, dan Kecamatan Brangsang merupakan daerah yang mengalami proses akresi yang lebih dominan sedangkan Kecamatan Kaliwungi merupakan daerah yang mengalami proses abrasi lebih dominan.

Analisis Net Shoreline Movement (NSM) menunjukkan bahwa sebagian besar abrasi terjadi pada periode 2000-2005 dan 2010-2015 dengan rata-rata abrasi sebesar 36,59 meter dan 53,39 meter sedangkan akresi terjadi pada periode 20052010 dan 2015-2020 dengan rata-rata abrasi sebesar 67,15 meter dan 23,49 meter. Analisis End Point Rate (EPR) menunjukkan hasil yang sama yakni periode 2000-2005 dan 2010-2015 merupakan periode tahun dengan proses abrasi yang tinggi dengan laju sebesar 8,27 meter/tahun dan 11,83 meter/tahun sedangkan periode tahun 2005-2010 dan 20152020 merupakan periode tahun dengan proses akresi yang lebih tinggi dengan laju sebesar 12,16 meter/tahun dan 4,50 meter/tahun.

Abrasi di Kabupaten Kendal berdampak kepada adanya kerusakan dan penurunan luasan tambak milik petani sedangkan akresi menyebabkan adanya peningkatan luas tambak dan luas wilayah ekosistem mangrove. Bentuk mitigasi yang dilakukan untuk mengurangi dampak dari proses akresi dan abrasi ini adalah dengan membangun ekosistem mangrove dan infrastruktur pelindung pantai di Pelabuhan Kaliwungu.

\section{UCAPAN TERIMA KASIH}

Ucapan terimakasih ditujukan kepada Dinas Pekerjaan Umum dan Penataan Ruang Kabupaten Kendal, Pemerintah Kabupaten Kendal, serta Departemen Geografi Lingkungan, Fakultas Geografi, Uiversitas Gadjah Mada atas bantuan yang diberikan untuk mendukung penelitian ini.

\section{KONTRIBUSI PENULIS}

Penulis pertama memimpin jalannya penelitian, menyusun metode penelitian, dan menyunting naskah. Penulis kedua menganalisis perubahan garis pantai dengan metode NSM. Penulis ketiga membuat dan menganalisis peta perubahan garis pantai. Penulis keempat mengolah data garis pantai dengan DSAS dan menganalisis perubahan garis pantai dengan metode EPR. Penulis kelima menganalisis perubahan garis pantai dengan metode LRR. Penulis keenam dan ketujuh melakukan wawancara dan menganalisis dampak serta upaya mitigasi perubahan garis pantai. Penulis kedelapan membimbing jalannya penelitian dan me-review naskah hasil penelitian.

\section{DAFTAR PUSTAKA}

Arief, M., Winarso, G., \& Prayogo, T. (2011). Kajian Perubahan Garis Pantai Menggunakan Data Satelit Landsat di Kabupaten Kendal. Jurnal Penginderaan Jauh, 8, 71-80.

Bidang Cipta Karya Kabupaten Kendal. (2020). Bab V Keterpaduan Strategi Pengembangan Kabupaten Kendal. Penyusunan Rencana Terpadu dan Program Investasi Infrastruktur Jangka 
Menengah (RPI2JM) Bidang CIpta Karya Kabupaten Kendal Kendal: Bidang Cipta Karya Kabupaten Kendal.

Dewi, I. N. C. (2019). Pemanfaatan Aplikasi Penginderaan Jauh dan Sistem Informasi Geografi untuk Proyeksi Perubahan Garis Pantai (Studi Kasus: Kota Semarang dan Sekitarnya). Skripsi.Yogyakarta: Universitas Gadjah Mada.

Diposaptono S, Budiman, Firdaus A. (2009). Menyiasati Perubahan Iklim di Wilayah Pesisir dan Pulau-Pulau Kecil. Bogor: PT. Sarana Komunikasi Utama.

Galloway, William E. (1975). Process framework for describing the morphologic and stratigraphic evolution of deltaic depositional systems. In: Broussard ML (ed) Deltas: models of exploration. Houston Geological Society, Houston, pp 87-98.

Hausmann, H. (2019). Soft vs Hard Engineering for Coastal Defense Adaptation. Climate Institute. New York. Diakses tanggal 24 November 2020 dari http://climate.org/soft-vs-hardengineering-for-coastal-defense-adaptation/.

Hazazi, G., Sasmito, B., \& Firdaus, H. S. (2019). Analisis Perubahan Garis Pantai Terhadap Eksistensi Mangrove Menggunakan Penginderaan Jauh dan Aplikasi Digital Shoreline Analysis System (DSAS) Tahun 2014-2018 (Studi Kasus区: Kabupaten Kendal). Geodesi Undip, 8(1), 19-27.

Himmelstoss, E.A., Henderson, R.E., Kratzmann, M.G., \& Farris, A.S., (2018). Digital Shoreline Analysis System (DSAS) version 5.0 user guide: U.S. Geological Survey Open-File Report 20181179, 110 p., https://doi.org/10.3133/ofr20181179.

Fajrin, F. M., Muskananfola, M. R., \& Hendrarto, B. (2016). Karakteristik Abrasi dan Pengaruhnya Terhadap Masyarakat di Pesisir Semarang Barat. Journal Management of Aquatic Resources 5. Universitas Diponegoro. Diakses tanggal 23 November 2020 dari http://ejournal-sl.undip.ac.id/index.php/maquares

Indarsih, R., \& Masruri, M. S. (2019). Mangrove conservation as an abration strategy risk reduction based on ecosystem in the coastal area of the Rembang Regency. IOP Conference Series: Earth and Environmental Science, 271, 012021. https:// doi.org/10.1088/1755-1315/271/1/012021

Istiqomah, F., B. Sasmito, \& F. Amarrohman. (2016). Pemantauan Perubahan Garis Pantai Menggunakan Aplikasi Digital Shoreline Anaysis System (DSAS) Studi Kasus囚: Pesisir Kabupaten Demak. Jurnal Geodesi Undip, 5(1), 78-79.

Kresteva, G. D., Rochaddi, B., \& Satriadi, A. (2014). Studi Kenaikan Muka Air Laut di Perairan Kendal. Jurnal Oseanografi, 3(4), 535 -539 .

Kurniawan, Irvan Agung. (2018). Dinamika Perubahan Garis Pantai Antara Muara Sungai Blorong dan Sungai Sibeo Tahun 1990 2017, Kabupaten Kendal. Skripsi. Yogyakarta: Universitas Gadjah Mada.

Leo van Rijin. (2010). Coastal Erosion Control Based On The Concept Of Sediment Cells. Diakses dari http://www.conscienceeu.net/documents/deliverable13a-controlling.pdf

Lumbanbatu, U.M., \& Hidayat, S. (2007). Evaluasi Awal Kerentanan Pelulukan/Likuefaksi Daerah Kendal dan Sekitarnya, Jawa Tengah. Jurnal Geologi Indonesia, 2, 159 - 176.

Mahendra, I. W. W. Y., Maulana, E., Wulan, T. R., Rahmadana, A. D. W., \& Putra, A. S. (2017). Pemetaan Kawasan Rawan Abrasi di Provinsi Jawa Tengah Bagian Utara. Bunga Rampai: Kepesisiran Dan Kemaritiman Jawa Tengah, 2, 93-105.

Marfai, M.A., Almohammad, H., Dey, Sudip., Susanto, B., \& King, Lorenz. (2008). Coastal Dynamic and Shoreline Mapping: Multisources Spatial Data Analysis in Semarang, Indonesia. Environ Monit Assess, 142(1-3), 297-308. DOI: 10.1007/s10661-007-9929 $-2$

Marfai, M.A. (2011). The Hazards of Coastal Erosion in Central Java, Indonesia: An Overview. Geografia Malaysia Journal of Society and Space, 7(3), 1-9.

Marfai, M.A. (2014). Impact of sea level rise to coastal ecology: A case study on the northern part of Java Island, Indonesia. Quaestiones Geographicae, 33(1), 107-114.

Marfai, M.A., Hizbaron, D.R., \& Mardiatno, D. (2015). Research Report International Research Collaboration and Scientific Pub- lication (Third Year): Coastal Geomorphological Hazard in North Central Java, Indonesia. Yogyakarta dan Amsterdam: UGM dan Vrije

Marfai, M.A., Tyas, D.W., Nugraha, I., Fitriatul'Ulya, A. \& Riasasi, W. (2016). The Morphodynamics of Wulan Delta and Its Impacts on the Coastal Community in Wedung Subdistrict, Demak Regency, Indonesia. Journal of Environmental Protection. 7: 60-71. http://dx.doi.org/10.4236/jep.2016.71006

Marfai, M. A., Rosaji, F. S. C. (2018). GIS Exercise Book Coastal Monitoring and Hazard Modelling. Yogyakarta: Badan Penerbit Fakultas Geografi (BPFG).

Muskananfola, Max Rudolf \& Sigit Febrianto. (2020). Spatiotemporal analysis of shoreline change along the coast of Sayung Demak, Indonesia using Digital Shoreline Analysis System. Regional Studies in Marine Science, 34

Mutaqin, Bachtiar. W. (2017). Shoreline Changes Analysis in Kuwaru Coastal Area, Yogyakarta, Indonesia: An Application of The Digital Shoreline Analysis System (DSAS). International Journal of Sustainable Development and Planning, 12(7), 12031214. DOI: 10.2495/SDP-V12-N7-1203-1214

Nathesan, U., Parthasarathy, A., Vishnuat, R., Kumar, G.E.J., \& Ferrer, V.A. (2015). Monitoring Longterm Shoreline Changes Along Tamil Nadu, India Using Geospatial Techniques. Aquatic Procedia, 4, 325-332

Richard, \& Sunarto. (2015). Perubahan Garis Pantai Dan Kerusakan Pantai Di Kawasan Kepesisiran Kabupaten Tuban Bagian Barat. Jurnal Bumi Indonesia 4(4), 1-10.

Sanjoto, T. B., Juhadi, \& S. B. Nugraha. (2019). Comparison of Delta Model in the North Coast of Central Java Using Remote Sensing Techniques (Case Study in Delta Comal, Delta Bodri and Delta Wulan). IOP Conference Series: Earth and Environmental Science, 243(1)

Satrio \& Taufiq, A. (2015). Studi Air Tanah Akuifer Dalam di Cekungan Semarang-Demak Menggunakan Isotop Alam 14C. Prosiding Pertemuan dan Penilaian Ilmiah BATAN, 79-82.

Seno, Hananto. (2020). Telephone Interview. 24 November 2020

Setyawan, A. D., \& Winarno, K. (2006). Permasalahan Konservasi Ekosistem Mangrove di Pesisir Kabupaten Rembang, Jawa Tengah. Biodiversitas, 7(2), 159-163.

Siregar, C., Handoyo, G., \& Rifai, A. (2014). Studi Pengaruh Faktor Arus dan Gelombang Terhadap Sebaran Sedimen Dasar di Perairan Pelabuhan Kaliwungu Kendal. Journal of Oceanography, 3(3) : 338-346.

Solihuddin, T., Kepel, T. L., Husrin, S., Pubani, D., Heriati, A., Ati, R. N. A.,Tusadiah, A. (2019). Strategi Rehabilitasi Pantura Jawa Berdasarkan Dinamika Wilayah Pesisir. Jakarta Pusat: AmaFrad Press. Diakses tanggal 24 November 2020 dari https:// iopscience.iop.org/article/10.1088/1755-1315/271/1/012021

Stephenson, W. (2016). Coastal Erosion. Dunedin. New Zealand : University of Otago.

Sunarto. (2000). Studi Geografi Pertumbuhan Bura dengan Acuan Pranata Mangsa pada Muara Sungai Opak \& Progo, Daerah Istimewa Yogyakarta. Laporan Penelitian. Yogyakarta: Fakultas Geografi UGM.

Sunarto, Marfai, M. A., \& Setiawan, M. A. 2014. Geomorfologi \& Dinamika Pesisir Jepara. Yogyakarta: UGM Press.

Wardhana, H.S., dan Susandi, A. (2015). Proyeksi Awal Musim di Jawa Berbasis Hasil Downscaling Conformal Cubic Armospheric Model (CCAM). Jurnal Sains Dirgantara, 13 (1),1 -14.

Wahib, M. (1993). Peta Geologi Tata Lingkungan Bersistem, Jawa Lembar Semarang dan Magelang Skala 1:100.000. Bandung: Direktorat Geologi Tata Lingkungan.

Winarso, Gathot, Haris Joko, \& Samsul Arifin. (2009). Kajian Penggunaan Data Inderaja Untuk Pemetaan Garis Pantai (Studi Kasus Pantai Utara Jakarta). Jurnal Penginderaan Jauh, 6, 6577. 